\title{
Production and Quality Evaluation of Water Yam: Sesame Based Snack (Akuto)
}

\author{
A. B. Adeniyi, J. K. Ikya, M. I. Yusufu
}

\begin{abstract}
Akuto is an old delicacy in Benue State. This nutritious delicacy has gone into extinction due to the emergence of new food products. An attempt has been made to convert this delicacy into high protein snacks using water yam tuber and sesame seeds. Boiled water yam tuber and toasted sesame seeds were blended in different proportions (A-100:0, B-90:10, C80:20, D-70:30, E-60:40, F-50:50) to produce Akuto snack. Products were analyzed for proximate composition, sensory and protein quality evaluation using rat assay. Results indicated that Sample A (100\% water yam) has highest acceptability from the sensory evaluation. There was significant increase in protein content with the inclusion of toasted sesame seed with values ranging from 5.06 to $20.08 \%$. Protein Efficiency ratio (PER) also increased with sesame supplementation and group $F$ had highest value 3.03. Biological Value (BV) and Net Protein Utilisation (NPU) was highest in reference diet group (G) $96.76 \%$ and $\mathbf{9 3 . 0 0 \%}$ followed by test diet group (F) $77.85 \%$ and $55.91 \%$ respectively.
\end{abstract}

Index Terms - Snack, Wateryam, Sesame seeds, Protein.

\section{INTRODUCTION}

Akuto is an old delicacy that is common in Benue State particularly among the Tiv people. This appetizing and nutritious delicacy is usually prepared by pounding water yam with salted sesame paste and red palm oil. It is consumed and enjoyed by both the old and young people. Akuto is gradually going into extinction because of the emergence of new food products and lack of knowledge on its nutritional benefits. Meanwhile, water yam and sesame seeds are in abundance in Benue State and are mainly utilized as staples with huge loss at postharvest stage.

However, consumer interest in ready-to-eat snack foods is constantly growing mainly due to their convenience, wide availability, appearance, taste and texture [1]. For many years, nutritionists have been concerned about snack eating behavior of the people [2] because majority of the snack products are based on cereals and grains which are low in protein content but high in calories and/or fat content [3]. Snack industries now focus on producing healthier snacks by reducing the amount of fat, sodium, sugar and increasing protein without losing the typical quality characteristics of these products [4]. It's been reported previously that the increased consumption

Published on October 25, 2020.

A. B. Adeniyi, Center for Food Technology and Research, Benue State University, Nigeria.

(e-mail: adesolabukola07@gmail.com)

J. K. Ikya, Federal University of Agriculture Makurdi, Nigeria.

M. I. Yusufu. of such foods that are high in fat and calories have been associated with increasing health problems, such as diabetes, cardiovascular disease, obesity, high blood pressure and breast cancer [5]-[7]. This has led the food industry to develop novel and healthier products fortified with functional ingredients for health conscious consumers [8]. Several researches have therefore been carried out by nutritionists to improve the nutritional value of snacks by incorporating protein from plant sources [9], [10]. These plant proteins have been shown to play significant roles in human nutrition, particularly in developing countries where average protein intake is less than the required. Due to these inadequate supplies of food proteins, there has been a constant search for unconventional protein sources, for use as both functional food ingredients and nutritional supplements.

Alkali et al. [11] worked on ojojo snack supplemented with bambara groundnut and observed increase in protein content with increased supplementation.

Idowu A. O [12] worked on kokoro snack made from maize and supplemented with African yam bean flour.

Gholam Reza Shaviklo et al. [13] developed extruded puffed corn snacks fortified with minced fish fillet which would be healthier than the widely consumed regular puffed corn snacks.

Angelica Loza et al. [14] developed functional cookies with wheat flour, banana flour and sesame seed

Fabian Uchenna \& Nwamaka, [15] developed quality bread fortified with sesame seed,

Fataneh et al. [16] developed puffed corn snacks incorporated with sesame seed powder. It is therefore necessary for snacks to be rich in proteins, fibres and have low glycemic response [17], [18].

Dioscorea alata commonly referred to as "winged yam", "water yam" or "greater yam" usually possesses tubers that are white, brown or brownish red in colour [19]. The water content of this tuber is usually high hence the name "water yam". Yam tubers of $D$. alata are also known for their high nutritional content, with crude protein content of $7.4 \%$, starch content of $75-84 \%$, and vitamin C content of 13.0$24.7 \mathrm{mg} / 100 \mathrm{~g}$ [20]. It is often recommended for diabetic patients and for weight reduction due to its low glycemic index [21]. Sesame seeds (Sesamum indicum) are tiny, flat oval seeds with a nutty taste. Sesame seed is a staple food among many ethnic groups in Nigeria and it is cultivated in most areas of the middle belt and some northern states of Nigeria [22]. Nigeria was ranked as the 5th largest producer of the commodity in the world in 2008, with an estimated production of 120,000 metric tons annually [23]. Sesame is an 
important source of oil (44-52.5\%), protein (18-23.5\%), carbohydrate (13\%) [24]. The seeds are consumed fresh, dried or blended with sugar. It is also used as paste in some local soups. Hence, it has potential use in food products as a protein supplement. In this regard, the research strives to develop Akuto snack from blends of full fat sesame seed and water yam tuber that would meet nutritional need and sensory requirement of the consumers.

\section{METHODOLOGY}

Water yam tuber (Choroko) and sesame seeds were purchased from Modern market in Makurdi, Benue State.

\section{A. Production of Akuto Snack}

The Dioscorea alata tuber was boiled for 15 mins on an electric heater and pounded while the Sesamum indicum seeds were sorted, washed and drained. The seeds were roasted in an electric oven at $150{ }^{\circ} \mathrm{C}$ for $90 \mathrm{~min}$ and milled; both samples were manually mixed at varying ratios, then shaped using hand pressed equipment. The shaped materials were dried in the oven at $70^{\circ} \mathrm{C}$ for $30 \mathrm{~min}$ to obtain the Akuto snack.

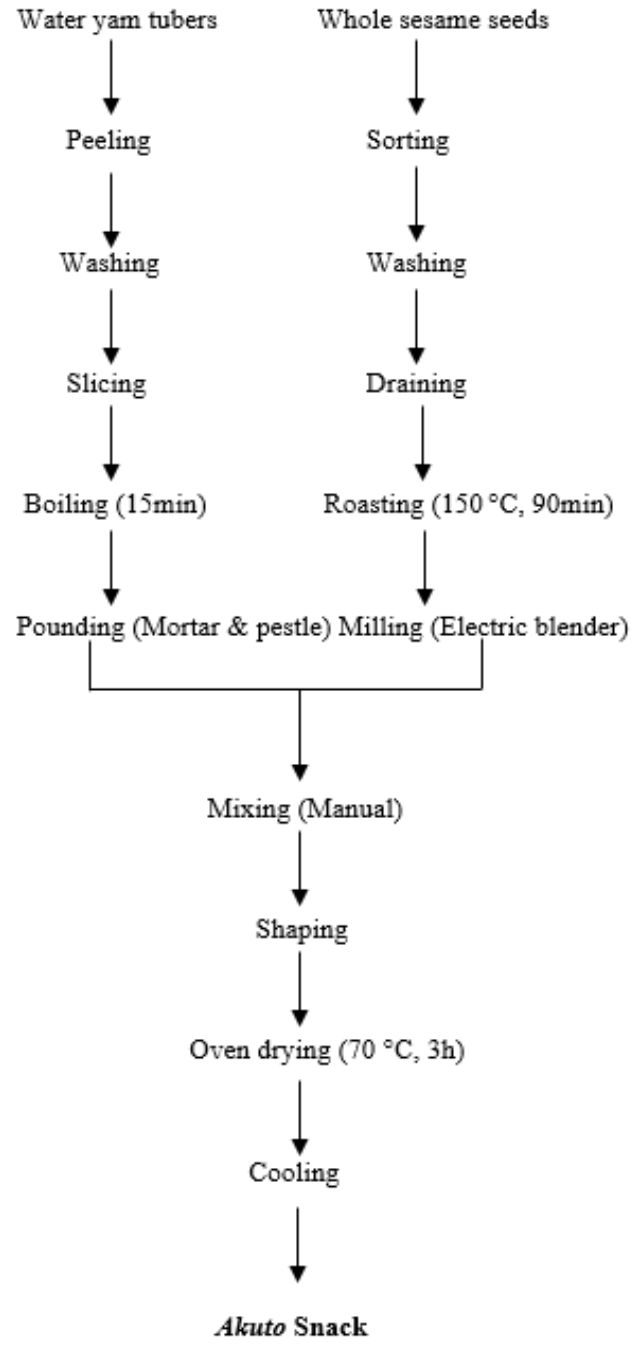

Fig. 1. Production of Akuto snack.

\section{B. Blend Formulation}

Six different blends were formulated based on boiled wateryam and full fat toasted sesame seed flour in the ratios of 100:0, 90:10, 80:20, 70:30, 60:40 and 50:50 respectively. The formulation was designed to obtain the products which have the highest protein content [25].

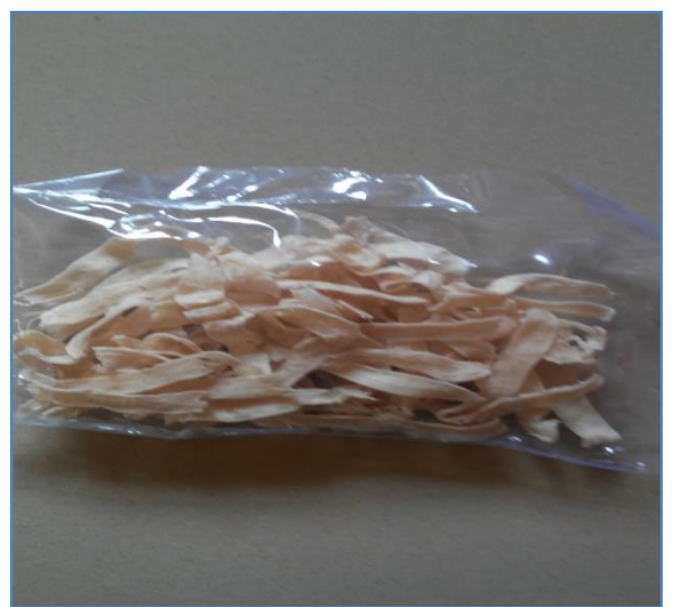

Fig. 2. Akuto snack(Sample A- 100:0).

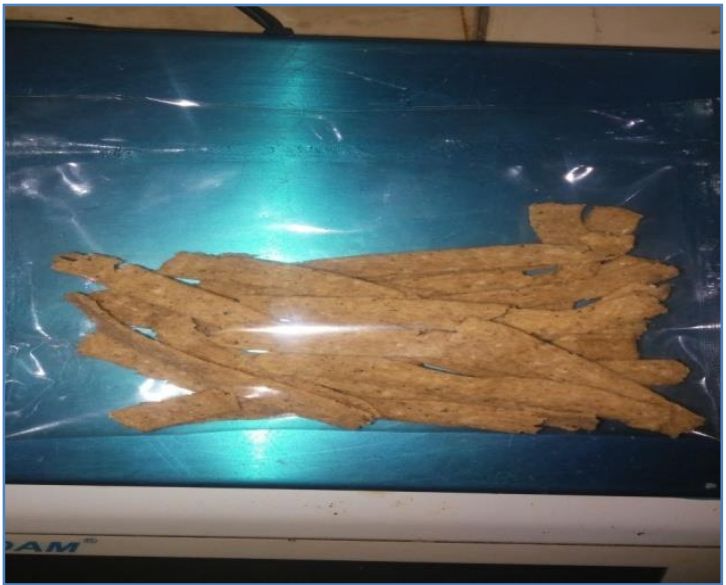

Fig. 3. Akuto snack (Sample C- 70:30).

\section{Proximate Analysis}

The proximate analysis (protein, fat, ash, moisture and crude fibre) of the blends was determined by the official methods of AOAC (2012) [26]. Carbohydrate was determined by difference (100 - the sum of the content of protein, fat, ash and moisture).

\section{Moisture content determination}

Five grams ( $5 \mathrm{~g})$ of the sample was weighed accurately into a pre-weighed clean dry dish provided with an easily removable lid. The uncovered dish was placed with its lid open in a well-ventilated oven maintained at $103{ }^{\circ} \mathrm{C}$ for $16 \mathrm{~h}$. The lid was replaced and transferred to a desiccator at a room temperature to cool for $30 \mathrm{~min}$, weighed immediately and the dish with the samples were replaced in the oven for $2 \mathrm{~h}$. The steps were repeated until decrease in mass between successive weights did not exceed $0.5 \mathrm{~g}$ (fresh weight basis). The loss in weight was reported as the moisture content. 


$$
\begin{gathered}
\% \text { Moisture content }=\frac{w 1-w 2}{w 1-w 0} \times 100 \\
w 0=\text { weight of empty petridish } \\
w 1=\text { Weight }(g) \text { of the sample and dish } \\
w 2=\text { Weight }(g) \text { of the dish and sample after drying } \\
w 1-w=\text { Weight of sample prepared for drying }
\end{gathered}
$$

\section{E. Crude protein determination}

Two gram of the sample was weighed into a digestion tube and $15 \mathrm{~mL}$ of concentrated $\mathrm{H}_{2} \mathrm{SO}_{4}$ was added to dissolve the sample. Kjedhal tablets were added to start up the digestion process in a fume cupboard preset at $410{ }^{\circ} \mathrm{C}$ for 45 min until a clear solution was observed. $75 \mathrm{~mL}$ of distilled water was added to prevent it from solidifying after digestion. The tubes were placed in a distilling unit and $50 \mathrm{~mL}$ of $40 \% \mathrm{NaOH}$ dispensed into the diluted solution, and the digested distillate into $25 \mathrm{~mL}$ of $40 \%$ boric acid for 5 mins. The distillate was titrated against $0.47 \mathrm{M}$ HCL until the first grey colour was seen. A blank was run first and the titre value was recorded.

$$
\begin{aligned}
& \% \text { Total Nitrogen } \\
& =\frac{\text { Titre value }- \text { Blank } \times 0.1 \times 0.0014 \times 6.25}{\text { Weight of sample }}
\end{aligned}
$$

$\%$ Protein $=$ Total nitrogen $\times$ conversion factor

Molecular weight of Nitrogen $=0.0014$

$$
\text { Conversion factor }=6.25
$$

\section{F. Ash content determination}

Two gram ( $2 \mathrm{~g}$ ) of the sample was weighed into an empty porcelain crucible that was previously ignited and weighed. The sample was ignited over a hot plate in a fume cupboard to char (burnt and black) organic matter. The crucible was thereafter placed in the muffle furnace maintained at a temperature of $600{ }^{\circ} \mathrm{C}$ for $6 \mathrm{~h}$. After ashing, it was then transferred directly to a desiccator and weighed immediately.

$$
\% \text { Ash }=\frac{(\text { Weight of the crucible }+ \text { Ash })-(\text { Weight of empty crucible }) \times 100}{\text { Weight of sample }}
$$

\section{G. Crude fat determination}

Crude fat was carried out using the method of AOAC 2012 [26]. Dried thimble was cleaned, weighed and recorded as $\left(\mathrm{W}_{1}\right) .5 \mathrm{~g}$ oven dried sample was added and re-weighed as $\left(\mathrm{W}_{2}\right)$. Round bottom flask was filled with petroleum ether (40$60{ }^{\circ} \mathrm{C}$ ) up to $3 / 4$ of the flask. Soxhlet extractor was fixed with a reflux condenser to adjust the heat sources so that the solvent boils gently, the samples were then transferred into thimble and inserted in the soxhlet apparatus and extraction under reflux was carried out with petroleum ether for $6 \mathrm{~h}$. After the barrel of the extractor was empty, the condenser and thimble were removed and taken into the oven at $100{ }^{\circ} \mathrm{C}$ for $1 \mathrm{~h}$ and later cooled in the desiccator. Weight was taken as $\left(\mathrm{W}_{3}\right)$.

$$
\begin{gathered}
\% \text { Fat }=\frac{\text { Weight loss of sample }(\text { extracted fat })}{\text { Original weight of sample }} \times 100 \\
=\frac{w 2-w 3}{w 2-w 1} \times 100
\end{gathered}
$$

\section{H. Crude fiber determination}

Two grams ( $2 \mathrm{~g}$ ) of the sample were weighed into the fibre flask and $100 \mathrm{~mL}$ of $0.225 \mathrm{M} \mathrm{H}_{2} \mathrm{SO}_{4}$ was dissolved into solution. The mixture was heated under efflux for $1 \mathrm{~h}$ using heating mantle; the hot mixture was filtered through a filter cloth. The filtrate obtained was discarded and the residue was poured into the flask to which $100 \mathrm{~mL}$ of $0.313 \mathrm{M} \mathrm{NaOH}$ was added and re-heated under reflux for another 1 hour. The mixture was filtered through a sieve cloth and $100 \mathrm{~mL}$ of acetone was added to dissolve any organic constituent present. The residue was washed with $50 \mathrm{~mL}$ of hot water twice on the sieve cloth before it was finally transferred into the crucible.

The crucible and the residue were dried in an oven at $150{ }^{\circ} \mathrm{C}$, cooled in a desiccator and weighed $\left(\mathrm{W}_{1}\right)$. The weighed sample was transferred to the muffle furnace for ashing at $550{ }^{\circ} \mathrm{C}$ for $4 \mathrm{~h}$. The crucible containing the ashed sample was cooled and weighed $\left(\mathrm{W}_{2}\right)$.

$$
\% \text { Crude fiber }=\frac{w 1-w 2}{\text { Weight of sample }} \times 100
$$

\section{Carbohydrate content determination}

Carbohydrate content determination was determined by difference.

$$
\begin{aligned}
\% \text { Carbohydrate }= & 100 \% \\
& -\%(\text { Protein }+ \text { Crude fat }+ \text { Ash } \\
& + \text { Moisture }+ \text { Crude fiber })
\end{aligned}
$$

\section{J. Sensory Evaluation of Akuto Snack}

Akuto snack made from blends of boiled water yam tuber and roasted sesame seed were subjected to sensory evaluation using twenty 20 panelist. The products were evaluated for appearance, texture, flavor, crispiness and overall acceptability. The ratings are on a 9-point hedonic scale ranging from 9 (like extremely) to 1 (dislike extremely) as outlined by Ihekoronye and Ngoddy 27].

\section{K. Protein Quality Evaluation}

Twenty seven albino rats (52-95 g) of about 7 weeks old, consisting of both male and female supplied by the animal house of the College of Health Science, Benue State University Makurdi were used. The rats were divided into nine (9) groups consisting of three (3) rats each. The rats were housed in individual cages placed on cardboard to allow collection of faeces.

Ten grams of each experimental diet (Table III) and water were fed to the rats ad libitum. Casein served as the control 
diet. The total food intake of the rats was determined by recording the food left after daily intake. Daily weight gain was determined by weighing the rats individually. Protein consumption was calculated from the food intake.

Animals were transferred into metabolic cages in the last 5 days of the experiment for the collection of urine and feaces. The individual faecal collections were dried in an air oven at approximately $60{ }^{\circ} \mathrm{C}$ to a constant weight. The dried faeces were weighed, ground into fine power and stored in a refrigerator until used for faecal Nitrogen determination. Urine was collected daily for 5 days and one $\mathrm{ml}$ of $0.1 \mathrm{~N}$ hydrochloric acid was added as a preservative to the urine samples to prevent the loss of ammonia. They were stored in a refrigerator until analyzed for urinary Nitrogen. At the end of the experimental period, the rats were weighed to get their final weight.

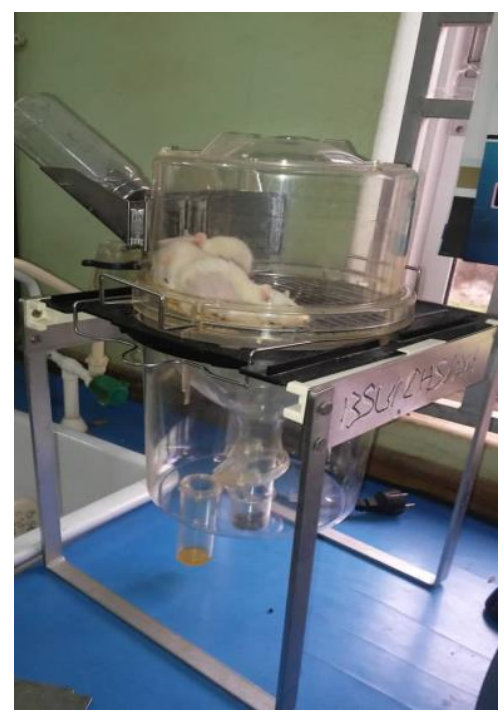

Fig. 4. Experimental rats in metabolic cage.

Determination of urinary and feacal nitrogen using Kjedhal method: Total nitrogen content was assessed by micro-Kjeldahl method AOAC [26]. Two gram of the sample was weighed into a digestion tube and $15 \mathrm{mls}$ of concentrated $\mathrm{H}_{2} \mathrm{SO}_{4}$ was added to dissolve the sample. Kjedhal tablets were added to start up the digestion process in a fume cupboard preset at $410{ }^{\circ} \mathrm{C}$ for $45 \mathrm{~min}$ until a clear solution was observed. $75 \mathrm{~mL}$ of distilled water was added to prevent it from solidifying after digestion. The tubes were placed in a distilling unit and $50 \mathrm{~mL}$ of $40 \% \mathrm{NaOH}$ dispensed into the diluted solution, and the digested distillate into $25 \mathrm{~mL}$ of $40 \%$ boric acid for $5 \mathrm{~min}$. The distillate was titrated against $0.47 \mathrm{M}$ HCL until the first grey colour was seen. A blank was run first and the titre value was recorded.

Data analysis: The data collected during the growth study were used in calculating the food intake, body weight gain and protein efficiency ratio (PER) of the diets. The urinary and faecal Nitrogen and Nitrogen intakes were used for calculating apparent $\mathrm{N}$ digestibility, $\mathrm{N}$ retention, net protein utilization (NPU \%) and biological value (BV \%) according to the formula given below [28].
Protein efficiency ratio $(\mathrm{PER})=$ Body weight gain in grams / Protein intakes in grams.

Nitrogen intake $(\mathrm{N}$-intake $)=$ food intake in grams $\mathrm{x} 0.016$. Nitrogen digestibility (digested nitrogen) $=\mathrm{N}$ intake (1) faecal nitrogen $(F)$

Nitrogen retention $(\mathrm{N}$ - balance $)=$ Digested nitrogen Urinary nitrogen $(\mathrm{U})$

Biological value $(\mathrm{BV} \%)=\mathrm{N}$-retention / Digested nitrogen X 100

Net protein utilisation $(\mathrm{NPU} \%)=\mathrm{N}$-retention $/ \mathrm{N}$-intake $\mathrm{X}$ 100.

\section{Statistical Analysis}

Data was presented as mean value \pm standard deviation of two replicates and analyzed by multiple factor analysis of variance (ANOVA) and correlation analyses using SPSS version 21. Multiple comparisons (post hoc Duncan multiple range test) were used to evaluate significant differences of the data at $\mathrm{p} \leq 0.05$ confidence limit.

\section{RESUlTS AND DISCUSSION}

The result of the proximate composition of Akuto snack is shown in Table I. The moisture content was within range and it was observed that control sample A with $100 \%$ water yam had the highest moisture content of $8.92 \%$, while sample with $50 \%$ sesame seed inclusion had the least moisture content of $2.34 \%$. However, a decrease in moisture content was observed as the proportion of sesame seed increases from 0-50\%. Ogundele [29] reported a decrease in moisture content of akara as a result of increase in protein from increased soybean supplementation. This also agrees with the report of Alkali et al. [30] that moisture decreases with increase in bambara groundnut supplementation. This could be attributed to the report of Sunful, Dixit $[31,32]$ that protein has some functional attributes such as water sorption, viscosity, elasticity, foamability and fibre formation which affect moisture content. The decrease in moisture level with increase in the level of sesame supplementation was suggested to be an indication of increase in storage ability as high moisture content in food has been shown to encourage microbial growth [33].

The protein content of the samples ranged from 5.06 to $20.08 \%$, while sample F with $50 \%$ sesame seed inclusion had the highest value. Protein is needed for growth, maintenance and regulation of the body process. The increase in protein content observed with supplementation of water yam with sesame seeds indicates that the nutritional quality of Akuto snack would be greatly improved. This could be due to the significant quality of protein in sesame seeds. Several studies [34], [35] have reported about $16-25 \%$ protein in sesame seeds while Udensi et al. [36] reported that water 
yam contains averagely $6.7 \%$ crude protein on a dry weight basis. This finding is in support with the work of Christine et al. [37] who reported highest protein content in sample supplemented with $30 \%$ sesame seed flour. Jimoh and Olatidoye [38] also reported increase in protein content with corresponding increase in soy flour supplementation in yam flour. Olayiwola [39] reported that the inclusion of cowpea flour significantly increased the protein content of cocoyam based "ojojo".

It was observed that fat content was highest in sample $\mathrm{F}$ and values ranges from 0.39 to 34.57 . Fat is important for providing energy for the body, storing energy for later use, insulating and protecting the body and transporting fat soluble vitamins [40]. Fat content increased upon sesame seed addition and values were higher than those reported by Christine [37]. The high fat content could be because sesame seeds comparatively has more fat $(38.54 \%)$ as reported by Blessing [35] than water yam (0.75-1.10\%) as reported by Udensi et al. [36]. This is evident in the control sample A (100\% water yam) which had the least fat content of $0.39 \%$ as compared with sample $\mathrm{F}$ containing $50 \%$ sesame which had the highest value of $34.57 \%$. This corresponds with the work of Banerjee and Kole [41] who reported decrease in fat content with decrease in sesame flour substitution from $30-10 \%$ (15.40-11.40) in beniseed composite flour baked foods. The relative increase in fat content could improve the energy level of the consumer as it has been known that one gram of fat or oil will yield about $368 \mathrm{KJ} / \mathrm{g} \mathrm{Kcal}$ of energy when oxidized in the body [42].

The result shows significant decrease in carbohydrate content with increased sesame seed supplementation at 0 month. Sample F with $50 \%$ sesame supplementation had the least carbohydrate content of $33.32 \%$ while the control A ( $100 \%$ water yam) had the highest value of $82.18 \%$. The decrease could be attributed to water yam which was reported to contain $81.53-87.64 \%$ [24], [36] while sesame seed contains relatively lower carbohydrate of about $62.23 \%$ [35].

TABLE I: PROXIMATE COMPOSITION OF AKUTO SNACK

\begin{tabular}{ccccccc}
\hline SAMPLES & MOISTURE & PROTEIN & ASH & FAT & FIBER & CARBOHYDRATE \\
\hline $\mathbf{A}$ & $8.92^{\mathrm{a}} \pm 0.14$ & $5.06^{\mathrm{f}} \pm 0.02$ & $1.50^{\mathrm{f}} \pm 0.10$ & $0.39^{\mathrm{f}} \pm 0.04$ & $1.95^{\mathrm{f}} \pm 0.05$ & $82.18^{\mathrm{a}} \pm 0.09$ \\
$\mathbf{B}$ & $8.08^{\mathrm{b}} \pm 0.06$ & $8.20^{\mathrm{e}} \pm 0.02$ & $2.09^{\mathrm{e}} \pm 0.01$ & $10.05^{\mathrm{e}} \pm 0.10$ & $2.76^{\mathrm{e}} \pm 0.05$ & $68.82^{\mathrm{b}} \pm 0.15$ \\
$\mathbf{C}$ & $6.26^{\mathrm{c}} \pm 0.32$ & $13.45^{\mathrm{d}} \pm 0.39$ & $2.85^{\mathrm{d}} \pm 0.35$ & $20.46^{\mathrm{d}} \pm 0.62$ & $3.49^{\mathrm{d}} \pm 0.08$ & $53.49^{\mathrm{c}} \pm 0.60$ \\
$\mathbf{D}$ & $4.47^{\mathrm{d}} \pm 0.12$ & $15.41^{\mathrm{c}} \pm 0.03$ & $3.46^{\mathrm{c}} \pm 0.05$ & $24.78^{\mathrm{c}} \pm 0.02$ & $3.76^{\mathrm{c}} \pm 0.04$ & $47.87^{\mathrm{d}} \pm 0.23$ \\
$\mathbf{E}$ & $3.12^{\mathrm{e}} \pm 0.08$ & $19.12^{\mathrm{b}} \pm 0.10$ & $4.09^{\mathrm{b}} \pm 0.01$ & $29.97^{\mathrm{b}} \pm 0.15$ & $4.27^{\mathrm{b}} \pm 0.03$ & $39.43^{\mathrm{e}} \pm 0.20$ \\
F & $2.34^{\mathrm{f}} \pm 0.10$ & $20.08^{\mathrm{a}} \pm 0.05$ & $4.82^{\mathrm{a}} \pm 0.18$ & $34.57^{\mathrm{a}} \pm 0.44$ & $4.88^{\mathrm{a}} \pm 0.02$ & $33.32^{\mathrm{f}} \pm 0.52$ \\
LSD & $\mathbf{0 . 2 8 5 4}$ & $\mathbf{0 . 2 9 7 5}$ & $\mathbf{0 . 2 9 6 9}$ & $\mathbf{0 . 5 6 9 5}$ & $\mathbf{0 . 0 8 6 5}$ & $\mathbf{0 . 6 2 9 8}$ \\
\hline
\end{tabular}

Values are mean \pm standard deviation of twenty replicates of data. Values with the same alphabet are not significantly different (pvalue $>0.05)$; LSD=least significant difference $. A=100 \%$ water yam, $\mathrm{A}=90 \%$ water yam: $10 \%$ sesame, $\mathrm{C}=80 \%$ water yam: $20 \%$ sesame, $\mathrm{D}=70 \%$ water yam: $30 \%$ sesame,E= $60 \%$ water yam: $40 \%$ sesame, $\mathrm{F}=50 \%$ water yam: $50 \%$ sesame, GA= General Acceptability.

The result of the sensory characteristic of Akuto snack is shown in Table II. Generally, it was observed that there was no significant difference in appearance, crispness, texture and flavor of the samples; except for colour in which sample A $(100 \%$ water yam) was significantly different $(7.60 \mathrm{a} \pm 0.94)$ from other samples while sample $F$ with the highest level of sesame had the least rating $(6.15 \mathrm{~b} \pm 1.27)$. This corresponds with the report of Fabian and Nwamaka [43] on sesame bread. However, sample A had the highest rating for all the sensory attributes while the values decreased with sesame inclusion. The effect of sesame seed level on the overall acceptability of the water yam-sesame based snack indicates that higher amounts of sesame in the formulation led to reduction in product acceptability. This could be attributed to the bitter taste of sesame seed since undehulled whole seeds were used to prepare the samples. This agrees with the report of Fatanneh et al. [44] on puffed corn snacks incorporated with sesame seed powder.

\begin{tabular}{|c|c|c|c|c|c|}
\hline SAMPLES & APPEARANCE & CRISPNESS & TEXTURE & FLAVOUR & GA \\
\hline $\mathbf{A}$ & $7.40^{\mathrm{a}} \pm 1.19$ & $7.25^{\mathrm{a}} \pm 1.37$ & $6.80^{\mathrm{a}} \pm 0.89$ & $6.85^{\mathrm{a}} \pm 1.14$ & $7.45^{\mathrm{a}} \pm 1.32$ \\
\hline B & $6.90^{\mathrm{a}} \pm 1.12$ & $6.80^{\mathrm{a}} \pm 1.28$ & $6.75^{\mathrm{a}} \pm 0.97$ & $6.20^{\mathrm{a}} \pm 1.06$ & $6.60^{\mathrm{a}} \pm 1.05$ \\
\hline $\mathbf{C}$ & $6.90^{\mathrm{a}} \pm 1.12$ & $6.45^{\mathrm{a}} \pm 1.15$ & $6.80^{\mathrm{a}} \pm 1.15$ & $6.20^{\mathrm{a}} \pm 1.15$ & $6.55^{\mathrm{a}} \pm 1.00$ \\
\hline D & $6.80^{\mathrm{a}} \pm 0.95$ & $6.25^{\mathrm{a}} \pm 1.12$ & $6.80^{\mathrm{a}} \pm 1.06$ & $6.50^{\mathrm{a}} \pm 1.24$ & $6.50^{\mathrm{a}} \pm 1.28$ \\
\hline $\mathbf{E}$ & $6.90^{\mathrm{a}} \pm 0.91$ & $6.30^{\mathrm{a}} \pm 1.69$ & $6.50^{\mathrm{a}} \pm 1.15$ & $6.40^{\mathrm{a}} \pm 1.35$ & $6.50^{\mathrm{a}} \pm 1.18$ \\
\hline $\mathbf{F}$ & $6.60^{\mathrm{a}} \pm 0.94$ & $5.90^{\mathrm{a}} \pm 1.89$ & $6.01^{\mathrm{a}} \pm 1.48$ & $6.50^{\mathrm{a}} \pm 1.61$ & $6.35^{\mathrm{a}} \pm 1.42$ \\
\hline LSD & NS & NS & NS & NS & NS \\
\hline P VALUE & 0.278 & 0.0653 & 0.293 & 0.606 & 0.0793 \\
\hline
\end{tabular}

Values are mean \pm standard deviation of twenty replicates of data. Values with the same alphabet are not significantly different (pvalue $>0.05) ;$ LSD $=$ least significant difference; $\mathbf{N S}=$ not significant at alpha $=\mathbf{0 . 0 5}$. A = 100\% water yam, $\mathrm{B}=90 \%$ water yam: $10 \%$ sesame,C= $80 \%$ water yam: $20 \%$ sesame, $\mathrm{D}=70 \%$ water yam: $30 \%$ sesame,E= 60\% water yam: $40 \%$ sesame, $\mathrm{F}=50 \%$ water yam: $50 \%$ sesame, $\mathrm{GA}=$ General Acceptability. 
TABLE III: COMPOSITION OF EXPERIMENTAL DIETS (G/100 G)

\begin{tabular}{|c|c|c|c|c|c|c|c|c|}
\hline \multirow{2}{*}{$\begin{array}{c}\text { COMPONENT OF } \\
\text { EXPERIMENTAL DIET } \\
\text { (G/100G) }\end{array}$} & \multicolumn{8}{|c|}{ SAMPLE CODE } \\
\hline & $\mathbf{A}$ & B & C & D & $\mathbf{E}$ & $\mathbf{F}$ & $\begin{array}{l}\text { G(casein } \\
\text { diet) }\end{array}$ & $\begin{array}{c}\text { H(protein free } \\
\text { diet) }\end{array}$ \\
\hline WATER YAM & 10 & 9.0 & 8.0 & 7.0 & 6.0 & 5.0 & 0 & 0 \\
\hline SESAME & 0 & 1.0 & 2.0 & 3.0 & 4.0 & 5.0 & 0 & 0 \\
\hline CASEIN(MILK PROTEIN) & 0 & 0 & 0 & 0 & 0 & 0 & 10 & 0 \\
\hline CORNSTARCH & 70 & 70 & 70 & 70 & 70 & 70 & 70 & 70 \\
\hline RICE HUSK & 1 & 1 & 1 & 1 & 1 & 1 & 1 & 1 \\
\hline SUGAR & 5 & 5 & 5 & 5 & 5 & 5 & 5 & 5 \\
\hline GROUNDNUT OIL & 8 & 8 & 8 & 8 & 8 & 8 & 8 & 8 \\
\hline $\begin{array}{c}\text { VITALYTE } \\
\text { (SALT/VITAMINS) }\end{array}$ & 6 & 6 & 6 & 6 & 6 & 6 & 6 & 6 \\
\hline RAT FEED & 0 & 0 & 0 & 0 & 0 & 0 & 0 & 0 \\
\hline TOTAL MASS (G) & 100 & 100 & 100 & 100 & 100 & 100 & 100 & 100 \\
\hline
\end{tabular}

The result of the growth performance of Albino rats fed Akuto snack is presented in Table IV. Feed intake of animals fed with casein-base diet $(\mathrm{G})$ was significantly $(\mathrm{p} \leq 0.05)$ higher than those fed with formulated diet (A-F) while feed intake of those fed with protein free diet $(\mathrm{H})$ was significantly lower than those fed the formulated diet (A-F). As regards these formulated diets, group A (100\% water yam) shows the highest feed intake per day. Similarly, the result showed that there was significant difference in body weight gain of the rats fed formulated diet (A-F) and casein-based diets (G). Groups $\mathrm{A}, \mathrm{B}, \mathrm{C}, \mathrm{H}$ had negative values because there was weight loss instead of weight gain.

Highest feed intake was observed in group (G), (C) and (A) respectively (482.00 g, $452.67 \mathrm{~g}$ and $456.50 \mathrm{~g})$. Despite the highest level of feed intake in groups $\mathrm{A}$ and $\mathrm{C}$, loss of weight was observed in the rats (90.32g-80.85 g, 83.50-80.67) while rats in group $(\mathrm{G})(70.32 \mathrm{~g}$ to $85.49 \mathrm{~g})$ showed highest level of weight gain. This indicates poor protein quality of diet A, C even though the rats consumed high amount. Those fed with test diet $\mathrm{A}, \mathrm{B}, \mathrm{C}$ and $\mathrm{H}$ (protein free diet) significantly lost weight when compared with $\mathrm{D}, \mathrm{E}, \mathrm{F}$ and $\mathrm{G}$. This agrees with the report of Toyoshima et al. [45] that growing rats fed a low protein diet showed reduced serum insulin followed by some growth retardation.

Generally it was observed that the rate of feed intake/28days was very low for experimental diets (B, C, D, E,
F) when compared with group A and rats fed casein diet. This could be attributed to the bitter taste of sesame seeds and the age of the experimental animals [46] that is they already prefer the taste of their feed. Loss of weight in A,B, C and D could be attributed to very low protein content in those test diets which is lower than 16\% RDA (Recommended Daily Allowance) protein recommended for growth by WHO (World Health Organization) [47].

PER is an index of protein quality. It indicates the relationship between weight gain in the test animals and the corresponding protein intake. The lower PER of rats fed test $\operatorname{diet} \mathrm{A}, \mathrm{B}, \mathrm{C}$ was not a surprise. The rats had negative body weight which affected the PER. Test diet F (3.43) had the highest PER followed by the casein group (3.03) which showed that both diets contained desirable pattern of EAA (Essential Amino Acids), which the animals used to synthesize new protein [48]-[50]. Supplementation with sesame seed gradually improved PER values, this could be attributed to utilization of the increased protein and micronutrients from sesame seed by the experimental animals. These observations are consistent with earlier reports of significant increase in PER in rats as a result of improved nutritional composition [51]. PER value greater than 2.0 is considered to be an excellent protein source, value below 1.5 indicates a protein of poor quality [52].

\begin{tabular}{|c|c|c|c|c|c|}
\hline & $\begin{array}{l}\text { AVR INITIAL } \\
\text { WEIGHT (G) }\end{array}$ & $\begin{array}{l}\text { AVR FINAL } \\
\text { WEIGHT (G) }\end{array}$ & $\begin{array}{c}\text { WEIGHT } \\
\text { GAIN(G/DAY) } \\
\end{array}$ & $\begin{array}{c}\text { FEED } \\
\text { INTAKE/28DAYS }\end{array}$ & PER \\
\hline A(CONTROL DIET) & $90.32 \pm 0.010^{\mathrm{a}}$ & $80.85 \pm 0.254^{\mathrm{b}}$ & $-9.33 \pm 0.000^{\mathrm{g}}$ & $456.50 \pm 0.000^{\mathrm{b}}$ & $-7.97 \pm 0.006^{\mathrm{h}}$ \\
\hline B & $79.66 \pm 0.012^{\mathrm{c}}$ & $71.66 \pm 0.012^{\mathrm{d}}$ & $-7.83 \pm 0.288^{f}$ & $411.40 \pm 0.100^{\mathrm{f}}$ & $-6.51 \pm 0.000^{\mathrm{g}}$ \\
\hline $\mathbf{C}$ & $83.50 \pm 0.006^{b}$ & $80.67 \pm 0.000^{c}$ & $-2.82 \pm 0.011^{\mathrm{e}}$ & $452.67 \pm 0.577^{\mathrm{c}}$ & $-1.24 \pm 0.006^{\mathrm{f}}$ \\
\hline D & $67.49 \pm 0.006^{\mathrm{e}}$ & $68.49 \pm 0.012^{\mathrm{f}}$ & $1.00 \pm 0.000^{\mathrm{d}}$ & $413.00 \pm 0.000^{\mathrm{e}}$ & $1.28 \pm 0.000^{\mathrm{d}}$ \\
\hline $\mathbf{E}$ & $64.83 \pm 0.000^{\mathrm{f}}$ & $66.49 \pm 0.012^{\mathrm{g}}$ & $1.66 \pm 0.010^{\mathrm{c}}$ & $415.00 \pm 0.000^{\mathrm{d}}$ & $1.91 \pm 0.000^{\mathrm{c}}$ \\
\hline $\mathbf{F}$ & $62.65 \pm 0.017^{\mathrm{g}}$ & $65.98 \pm 0.028^{\mathrm{h}}$ & $3.33 \pm 0.006^{\mathrm{b}}$ & $410.67 \pm 0.577^{\mathrm{g}}$ & $3.43 \pm 0.010^{\mathrm{a}}$ \\
\hline \multirow{3}{*}{$\begin{array}{c}\text { G(CASEIN GRP) } \\
\text { H(PROTEIN FREE } \\
\text { GRP) }\end{array}$} & $70.32 \pm 0.010^{\mathrm{d}}$ & $85.49 \pm 0.010^{\mathrm{a}}$ & $15.17 \pm 0.010^{\mathrm{a}}$ & $482.00 \pm 1.000^{\mathrm{a}}$ & $3.03 \pm 0.006^{\mathrm{b}}$ \\
\hline & $61.33 \pm 0.000^{\mathrm{h}}$ & $46.00 \pm 0.006^{\mathrm{i}}$ & $-15.33 \pm 0.000^{\mathrm{h}}$ & $374.00 \pm 0.000^{\mathrm{h}}$ & $0.00 \pm 0.000^{\mathrm{e}}$ \\
\hline & 0.001 & 0.001 & 0.001 & 0.001 & 0.001 \\
\hline
\end{tabular}


The result of urinary nitrogen, feacal nitrogen, biological value (BV) and net protein utilization (NPU) of the formulated diets (A,B,C,D,E,F) and casein based diet $(G)$ are presented in Table V. There was significant increase in BV for all the diets and this value increased with increased sesame inclusion in the formulated diets (A- $48.87 \%$ to F- 77.85\%). The casein based diet group (G) had highest values of Biologcial value (96.76\%) and Net Protein Utilization (93.00\%) as compared to the formulated diets. These low values observed in the formulated diets for both PER and BV confirms the report of Young and Pellett [53] that plant proteins are generally not well digested and assimilated when compared to animal proteins. The higher NPU value for the rats fed casein based diet $(\mathrm{G})$ could be due to higher retained nitrogen, which implies that they have better quality protein sources compared to other formulated diets.

TABLE V: Nitrogen Intake, FaeCAl, Digested, Urinary, ANd Retained Nitrogen, Biological Value And Net Protein Utilization

\begin{tabular}{cccccccc}
\multicolumn{7}{c}{ OF RATS FED AKUTO SNACK } \\
\hline & N INTAKE(G) & FEACAL N(G) & URINARY N(G) & DIGESTED N(G) & RETAINED N & BV\% & NPU\% \\
\hline A & $2.43 \pm 0.005^{\mathrm{b}}$ & $1.10 \pm 0.000^{\mathrm{a}}$ & $0.67 \pm 0.013^{\mathrm{a}}$ & $1.33 \pm 0.000^{\mathrm{d}}$ & $0.65 \pm 0.010^{\mathrm{g}}$ & $48.87 \pm 0.000^{\mathrm{g}}$ & $26.75 \pm 0.000^{\mathrm{g}}$ \\
B & $2.19 \pm 0.005^{\mathrm{d}}$ & $0.87 \pm 0.010^{\mathrm{e}}$ & $0.61 \pm 0.006^{\mathrm{c}}$ & $1.31 \pm 0.006^{\mathrm{e}}$ & $0.70 \pm 0.006^{\mathrm{f}}$ & $53.43 \pm 0.006^{\mathrm{f}}$ & $31.95 \pm 0.012^{\mathrm{f}}$ \\
$\mathbf{C}$ & $2.42 \pm 0.010^{\mathrm{c}}$ & $0.96 \pm 0.006^{\mathrm{c}}$ & $0.65 \pm 0.006^{\mathrm{b}}$ & $1.44 \pm 0.006^{\mathrm{c}}$ & $0.78 \pm 0.000^{\mathrm{d}}$ & $54.17 \pm 0.000^{\mathrm{e}}$ & $32.23 \pm 0.000^{\mathrm{e}}$ \\
$\mathbf{D}$ & $2.20 \pm 0.000^{\mathrm{de}}$ & $1.00 \pm 0.000^{\mathrm{b}}$ & $0.48 \pm 0.000^{\mathrm{d}}$ & $1.20 \pm 0.006^{\mathrm{g}}$ & $0.72 \pm 0.006^{\mathrm{e}}$ & $59.98 \pm 0.028^{\mathrm{d}}$ & $32.72 \pm 0.010^{\mathrm{d}}$ \\
$\mathbf{E}$ & $2.21 \pm 0.006^{\mathrm{e}}$ & $0.94 \pm 0.010^{\mathrm{d}}$ & $0.44 \pm 0.006^{\mathrm{e}}$ & $1.27 \pm 0.000^{\mathrm{f}}$ & $0.83 \pm 0.006^{\mathrm{c}}$ & $65.35 \pm 0.010^{\mathrm{c}}$ & $37.56 \pm 0.000^{\mathrm{c}}$ \\
F & $2.20 \pm 0.000^{\mathrm{de}}$ & $0.62 \pm 0.005^{\mathrm{f}}$ & $0.35 \pm 0.000^{\mathrm{f}}$ & $1.58 \pm 0.006^{\mathrm{b}}$ & $1.23 \pm 0.006^{\mathrm{b}}$ & $77.85 \pm 0.000^{\mathrm{b}}$ & $55.91 \pm 0.010^{\mathrm{b}}$ \\
$\mathbf{G}$ & $2.56 \pm 0.010^{\mathrm{a}}$ & $0.10 \pm 0.000^{\mathrm{g}}$ & $0.08 \pm 0.006^{\mathrm{g}}$ & $2.47 \pm 0.000^{\mathrm{a}}$ & $2.39 \pm 0.010^{\mathrm{a}}$ & $96.76 \pm 0.005^{\mathrm{a}}$ & $93.00 \pm 0.000^{\mathrm{a}}$ \\
& 0.001 & 0.001 & 0.001 & 0.001 & 0.001 & 0.001 & 0.001 \\
\hline
\end{tabular}

Values are mean \pm standard deviation of twenty replicates of data. Values with the same alphabet are not significantly different (pvalue $>0.05)$;
LSD=least significant difference; $\boldsymbol{N S}=$ not significant at alpha $=\mathbf{0 . 0 5} . \mathrm{A}=100 \%$ water yam, $\mathrm{B}=90 \%$ water yam: $10 \%$ sesame,C=80\% water yam: $20 \%$ sesame, $\mathrm{D}=70 \%$ water yam: $30 \%$ sesame, $\mathrm{E}=60 \%$ water yam: $40 \%$ sesame, $\mathrm{F}=50 \%$ water yam: $50 \%$ sesame, $\mathrm{G}=$ casein group.

\section{CONCLUSION}

It is apparent that substituting water yam with whole sesame seed for Akuto snack improved the nutrient composition of the product in terms of increase in protein, fiber content and decrease in carbohydrate content. Though the sensory quality was adversely affected as the control sample A containing $100 \%$ water yam was the most accepted by the panelists. This could be as a result of the bitter taste of sesame seed. From the study, it can also be concluded that substituting water yam with whole sesame seed drastically improved Protein Efficiency Ratio, Biological Value, Net Protein Utilization in samples D, E and F. Sample F substituted with $50 \%$ toasted sesame seeds gave PER, BV, NPU values that compared favourably with the reference diets (casein group $\mathrm{G}$ ) in the parameters investigated. Therefore, to improve the sensory acceptability of Akuto snack, spices and flavours could be added during its production. The snack could also be a good snack for those who want to lose weight and those who suffer from diabetes.

\section{REFERENCES}

[1] M. Omwamba, S, Mahungu, Development of a protein rich ready-to-eat extruded snack from a composite blend of rice, sorghum and soybean flour. Food and Nutrition Sciences. 2014, p5:1309-1317.

[2] P. Tangkanakul, P. Tungtrakul and W. Mesomya, Nutrient contents of commercial snack food products. Kasetsart Journal of Natural Science. 1999, 33:270-276

[3] S. Struck, D. Jaros, C. S. Brennan and H. Rohm, Sugar replacement in sweetened bakery goods. International Journal of Food Science and Technology, 2014, 49(9), 1963-1976.

[4] Pavan Kumar, O.P. Malav (2019). Innovations in Traditional Foods.

[5] Dingemans, A. E., Martijn, C., van Furth, E. F., and Jansen, A. T. M.(2009). Expectations, mood, and eating behavior in binge eating disorder. Beware of the bright side. Appetite, 53(2), 166-173.

[6] Granner, M. L., Sargent, R. G., Calderon, K. S., Hussey, J. R., Evans, A. E., and Watkins, K. W. (2004). Factors of Fruit and Vegetable Intake by Race, Gender, and Age among Young Adolescents. Journal of Nutrition Education and Behavior, 36(4).
[7] Shaviklo, G. R., Olafsdottir, A., Sveinsdottir, K., Thorkelsson, G., and Rafipour, F. (2011). Quality characteristics and consumer acceptance of a high fish protein puffed corn-fish snack. Journal of Food Science and Technololgy, 48(6), 668-676.

[8] Popkin, B. M and Duffe,y, K. J, (2010). Does hunger and satiety drive eating anymore? Increasing occasions and decreasing time between eating occasions in the United States. American Journal of Clinical Nutrition, 91:1342-1347.

[9] Chang, Y. K., Hashimoto, J. M., Acioli-Moura R, Martinez-Flores, H. E., MartinezBustos F. (2001). Influence of extrusion conditions on cassava starch and soybean protein concentrate blends. Acta Alimentaria, 30(2): 189203.

[10] Hashimoto, J. M, Nabeshime, E. H., Cintra, H. S., Guerra-Dias, A. R, Bustos FM, Chang KY (2002). Effect of processing conditions on some functional characteristics of extrusion-cooked cassava starch/wheat gluten blends. J. of the Sci. and Food Agric., 82(8): 924-930.

[11] Alakali J. S., Okache T. A., Agomuo J. K. (2016). Effects of Bambara Groundnut Supplementation on the Quality of ojojo a Water Yam Based Snacks. International Journal of Nutrition and Food Sciences, Volume 5, Issue 6, Pages: 422-428.

[12] Idowu A. O. (2015). Nutrient composition and sensory properties of kokoro (a Nigerian snack) made from mize and African yam bean flour blends. International Food Research Journal, 22(2): 739-744.

[13] Gholam Reza Shaviklo, Adalheidur Olfsdottir, Kolbrun Sveinsdottr, Gudjon Thorkelsson, Fereidoon Rafipour. (2011). Quality characteristics and consumer acceptance of a high fish protein puffed corn-fish snack. Journal of food science and technology. 48(6): 668676.

[14] Angelica Loza, Merley Quispe, Juan Villanueva, Pedro P., Pelaez. (2017). Development of functional cookies with wheat flour, banana flour (Musa paradisiaca), sesame seeds (Sesamum indicum) and storage stability. Scientific journal of Universidad Nacional de Trujillo; Vol. 8, No 4, 2306-6741.

[15] Fabian Uchenna Ugwuona \& Nwamaka A., Obeta. (2016). Quality Characteristics of Breads Fortified with Sesame Seed. Volume 16 Iss 2. ISSN: 2249-4618.

[16] Fataneh Hashempour-Baltork, Mohammadali Torbati, Sodeif Azadmard-Damirchi, Geoffrey P., Savage. (2017). Quality properties of puffed corn snacks incorporated with sesame seed powder.

[17] Hu, F. B. (2005). Protein, body weight, and cardiovascular health. The American Journal of Clinical Nutrition, 82(1), 242-247.

[18] Marsh, S., Ni Mhurchu, C., Jiang, Y., and Maddison, R. (2014). Comparative effects of TV watching, recreational computer use, and sedentary video game play on spontaneous energy intake in male children. A randomised crossover trial. Appetite, 77(0), 13-18. 
[19] C. K. Riley, A. O. Wheatley, H. N. Asemota, Isolation and characterization of starches from eight Dioscorea alata cultivars grown in Jamaica. African Journal of Biotechnology, 2006, 5 (17): 1528-1536.

[20] Souleymane Sorh, Fankroma Martial Thierry Koné, Siaka Binaté, Soumaïla Dabonné and Lucien Patrice Kouamé, Nutritional composition and enzyme activities changes occurring in water yam (dioscorea alata) cultivar "brazo" during the postharvest storage. International Journal of Food and Nutritional Sciences, 2015, Vol. 4, Iss. 4.

[21] A. O. Oko and A. C. Famurewa, Estimation of Nutritional and Starch Characteristics of Dioscorea alata (Water Yam) Varieties Commonly Cultivated in the South-Eastern Nigeria. British Journal of Applied Science and Technology, 2015, 6, 145-152

[22] T. M. A. Olanyanju, R. Akinoso, M. O. Oresanya, Effect of wormshaft speed, moisture content and variety on oil recovery from expelled beniseed. Agricultural Engineering International. 2006, 8:1-7.

[23] Food and Agricultural Organization of the United Nation (FAOSTAT ), FAO Statistics Division Database, 2010.

[24] A. Y. Bamigboye, A. C. Okafor, O. T. Adepoju, Proximate and mineral composition of whole and dehulled Nigerian sesame seed. African Journal of Food Science and Technology, 2010, 1(3):71-5.

[25] M. A. Akpapunam, G. I. O. Badifu and E. P. Etokudo, Production and quality characteristics of Nigerian Agidi supplemented with soy flour. Journal of Food Science and Technology, 1997, 34:143-145.

[26] AOAC, Official methods of analysis, 18th edn. Association of Official; Analytical Chemists, Washington DC, 2012.

[27] A. I. Ihekoronye and P. O. Ngoddy, Intergrated Food Science and Technology for the Tropics. Macmillian Publishers Ltd., London, ISBN: 9780333388839, 1985, pp: 109.

[28] V. N. Mode, Growth, Nitrogen Utilisation and Liver Composition of Rats Fed Mixtures of Processed and Unprocessed Cereal and Legume Diets. Journal of Agriculture, Food, Environment and Extension, 2005, Volume 4, Number 1, pp 38-42, ISSN 1119-7455.

[29] G. F. Ogundele, B. A. Ojubanire and O. P. Bamidele, Evaluation of various characteristics of akara (fried beans cake) made from cowpea (vignaunguiculata) and soybean (glycine max) blends. Journal of Experimental Biology and Agricultural Sciences, 2014, Vol. 2 (5).

[30] J. S. Alakali, T. A. Okache, J. K. Agomuo, Effects of Bambara Groundnut Supplementation on the Quality of ojojo a Water Yam Based Snacks. International Journal of Nutrition and Food Sciences, 2016, Vol. 5, No. 6, pp. 422-428.

[31] R. E. Sunful, A. Sadik, S. Darko, Nutritional and Sensory analysis of soybean and wheat flour composition cake. Pakistan Journal of Nutrition, 2010, 9:794-796.

[32] A. K. Dixit, J. I. X Anthony, N. K. Sharma, R. K. Tiwari, Soybean consistent and their functional benefits, In: Tiwari V. K, Mishra B. B. (Eds) Opportunity, challenge and scope of natural products in Medicinal Chemistry, Research Signpost Publication, 2011, Kerala, India pp. 367-383.

[33] V. J. Temple, E. J. Badamosi, O. Ladeji and M. Solomon, Proximate, chemical composition of three locally foundamental complementary foods. West African Journal of Biological Sciences, 1996, 5:134-143.

[34] Kandangath Raghavan, Nutritional, Medicinal and Industrial Uses of Sesame (Sesamum indicum L.) Seeds. Biochemistry and Nutrition Discipline, Defence Food Research Laboratory, Mysore, 2010, Vol. 75 (2010) No. 4 (159-168).

[35] M. Blessing, O. Garuba, U. Augustina, O. Sunday, Chemical Composition of Sesamum indicum L. (Sesame) Grown in Southeastern Nigeria and the Physicochemical Properties of the Seed Oil. Seed Science and Biotechnology, 2010, 4(1), 69-72.

[36] E. A. Udensi, H. O. Oselebe and A. U. Onuoha, Antinutritional assessment of D. alata varieties. Pakistan Journal of Nutrition, 2010, 9: 179-181.

[37] E. Christine, E. Christopher, I. Godwin, Nutritional and Organoleptic Properties of Wheat (Triticum aestivum) and Beniseed (Sesame indicum) Composite Flour Baked Foods. Journal of Food Research, 2012, Vol. 1, No. 3; ISSN 1927-0887.

[38] K. O. Jimoh and O. P. Olatidoye, Evaluation of Physicochemical and rheological characteristics of soybean fortified yam flour. Journal of Applied Biosciences, 2009, 13:703-706.

[39] I. Olayiwola, F. Folaranmi, A. Abdul-Rasaqi, O. Oluseye, A. Ajok and A. Wasiu, Chemical, Mineral composition and Sensory acceptability of cocoyam-based recipes enriched with cowpea flour. African Journal of Food and Nutrition, 2013, 13: 228-234.

[40] G. M. Wardlaw and M. Kessel, Water and major minerals. Perspective in nutrition. 2002, (5 ${ }^{\text {th }}$ ed.) p453.

[41] P. P. Banerjee, P. C. Kole, Analysis of genetic architecture for some physiological characters in sesame (Sesamum indicum L.). 2009, Euphytica 168: 1122.

[42] J. S. Oliveira, Grain legumes of Mozambique; Tropical Grain Legume Bulletin, 1976.

[43] Fabian Uchenna Ugwuona \& A. Nwamaka, Obeta, Quality Characteristics of Breads Fortified with Sesame Seed, 2016, Volume 16 Iss 2. ISSN: 2249-4618.

[44] Fataneh Hashempour-Baltork, Mohammadali Torbati, Sodeif Azadmard-Damirchi, P. Geoffrey, Savage, Quality properties of puffed corn snacks incorporated with sesame seed powder, 2017.

[45] Y. Toyoshima, R, Tokita, Y. Taguchi, N. Akiyamakanshi and A. Takenaka, Tissue-specific effects of protein malnutrition on insulin signaling pathway and lipid accumulation in growing rats. Endocrine Journal, 2014, 61(5), 499-512.

[46] D. J. Millward, D. K. Layman, D. Tome, Protein quality assessment: Impact of expanding understanding of protein and amino acid needs for optimal health. American Journal of Clinical Nutrition, 2008, 87, 1576S-1581S

[47] WHO (World Health Organisation), Energy and Protein Requirements. Report of a Joint FAO/WHO/UNU Expert Consultation. Technical Report Series 724. World Health Organization, Geneva. 1985, Pp 206.

[48] M. O. Alabi, J. C. Anuonye, C. F. Ndaeji, A. A. Idowu, Comparison of the growth and development of selected children in soybean and non soybean producing and utilization of villages in Niger State, Nigeria. PolyMath Journal. 2001, 2:8-12.

[49] C. J. U. H. K. Chai, S. C. Kim, Determination of bioactive compounds in fermented soybean products using GC/MS and further investigation of correlation of their bioactivities. J. Chromatogr. B Analyt Journal of Technology in Biomedical and Life Sciences. 2011, 880(1):42-49.

[50] T. O. Osungbaro, Y. A. Esuoso, K. O. Esuoso, Physical and nutritive properties of fermented cereal foods. African Journal of Food Science. 2009, 3(2):023-027.

[51] M. O. Oluwamukomi, A. F. Eleyemi, V. N. Enujiugha and S. O. Atofarati, Nutritional, Physico-Chemical and Sensory Evaluation of Sorghum and Cowpea based Complementary Formulations. Nigerian Food Journal, 2003, 21, 11-17.

[52] C. F. Onwuka, C. C. Ikewuchi, C. J. Ikewuchi and O. E. Ayalogu, "Effect of Germination on the Performance Characteristics of African Yam Bean (Sphenostylis stenocarpa Hochst ex A Rich) Seed Meal on Albino Rats". Journal of Applied Sciences and Environment Management, 2009, vol. 13, No 2, pp 51-53.

[53] V. R. Young and P. L. Pellett, "Plant proteins in relation to human protein and amino acid nutrition", American Journal of Clinical Nutrition, 1994, vol. 59, no. 5, pp. 1203-1212. 